Предраг Мутавџић

Филолошки факултет у Београду

Катедра за неохеленске студије

predrag.mutavdzic@fil.bg.ac.rs

\section{Мерима Кријези}

Филолошки факултет у Београду

Катедра за албанологију

merima.krijezi@fil.bg.ac.rs
УДК 811.18`373.7:811.163.41`373.7

https://doi.org/10.18485/slavistika.2021.25.1.24

Оригинални научни рад примљено 13.05.2021.

прихваћено за штампу 17.06.2021.

\title{
О БИБЛИЈСКИМ ФРАЗЕОЛОГИЗМИМА СА ОНОМАСТИЧКОМ КОМПОНЕНТОМ У САВРЕМЕНОМ АЛБАНСКОМ И СРПСКОМ ЈЕЗИКУ
}

У раду су контрастивно анализирани фразеологизми са ономастичком компонентом као главним лексичким елементом у албанском и српском језику. У односу на смер кретања, албански је сагледан као полазни а српски као циљни језик. У анализи указујемо на степен њихове еквиваленције и/или дивергенције када је реч о морфолошко-лексичкој структури и о семантичком опсегу који поменути фразеологизми поседују и апстрахују. Отуда је извршена њихова класификација према структурној и семантичкој еквиваленцији у којој су се издвојиле две велике подгрупе, прву чине апсолутно семантичко и структурно подударни фразеологизми, а другу - они са нешто разноврснијом структуром (услед могућих лексичких комутација унутар фразеологизама) али истоветне семантике. Анализом је такође указано и на постојање релативно фреквентних фразеологизма у албанском који нису забележени у српској језичкој грађи.

Кључне речи: библизми, фразеологизми, ономастичка компонента, антропоними, топоними, албански, српски, контрастивна анализа.

In the paper we examine biblical idiomatic expressions in contemporary Albanian and Serbian containing onomastic components as their key lexemes from the contrastive perspective. At the same time we indicate the degree of their equivalence and/or divergence bearing in mind their morphological and lexical structures as well as of their semantic correspondence. Albanian is considered as a source language and Serbian as a target one. All the idiomatic expressions are grouped into two main fields - the first one is consisted of semantically and structurally identical units, the second group represent idiomatic expressions with their slightly diverse structures (due to possible commutations of lexemes within the idioms) but contain and express the same meaning. Our analysis also shows that there are some idiotypical idiomatic features of Albanian which cannot be found in the examined Serbian corpus and which have been used very frequently in everyday communication.

Keywords: biblical idiomatic expressions, onomastic components, anthroponyms, ethnonyms, toponyms, Albanian, Serbian, contrastive analysis.

\section{1. ЦИљ, МЕТОДОЛОГИЈА, КОРПУС}

У нашем раду разматрамо албанске и српске фразеологизме и паремије који садрже као кључну ономастичку компоненту библијски антропоним, топоним или етноним. Њих у оба језика контрастивно упоређујемо, настојећи да утврдимо њихов степен структурне и семантичке еквиваленције и да укажемо да ли између њих преовлађује међујезичка, међулексичка и међуфразеолошка конвергенција 
или дивергенција. У смеру посматрања, албански је полазни а српски циљни језик. Ако у албанском примеру постоји одступање у односу на српски, структурна разлика је подвучена, а фразеологизам и/или паремија у нултој структурносемантичкој еквиваленцији означен је звездицом и дат као глоса.

Разлог нашег опредељења за разматрање ових фразеологизама инспирисан је чињеницом да је име важна друштвена, психолошка и културна појава - зато за старе Латине nomen est omen, у слободном преводу „све је у имену” - у виду одлике да „се код свих народа на свету, и у ранијим и у савременим културама, уочава придавање значаја имену као трајној или узрасно променљивој ознаци лица“ (Кончаревић 2018a: 92-93). Библијска имена чврсто инкорпорирана у ономастички свет хришћана, културно су прихваћена и/или су постала позната и у другим нехришћанским друштвима. Савремено албанско друштво се данас сагледава религијски двојако, будући поларизовано на мањински, хришћански (православни и римокатолички), и на већински, исламизирани, део ${ }^{1}$ који je у културолошком погледу сачувао многе додирне тачке са хришћанском традицијом - једну од њих оличава раширена употреба различитих библизама.

Грађа је ексцерпирана из одабраног корпуса штампаних и online једнојезичних и двојезичних речника, објављених на оба језика, чији је списак приложен у одељку Извори на крају рада. Ради додатне провере основних и изведених значења забележених фразеолошко-паремиолошких конструкција, као и њихове учесталости у језику, послужили смо се и резултатима добијеним путем претраживача Google.

\section{2. О БИБЛИЈСКИМ ФРАЗЕОЛОГИЗМИМА СА ОНОМАСТИЧКОМ КОМПОНЕНТОМ}

Библија је, као што је добро познато из историје, јединствен текст вековима у служби као кључно штиво које је нудило знање, давало практичне одговоре на бројна питања и пружало савете о образовању, моралном владању и васпитању. И данас, када се Библија проучава из свеобухватније, свестраније и интердисциплинарније перспективе, њен смисао и значај нису изгубљени, што најбоље показује и податак да је то и даље једна од најпродаванијих, највише штампаних и превођених ${ }^{2}$ књига на читавом свету (Јовановић 2003).

Због непосредног додира са библијским текстом, било је природно да у језик сваког хришћанског народапостепеноуђупоједини библизмиу виду фразеолошких конструкција и паремија где се као кључна реч појављује ономастичка компонента у виду антропонима, етнонима и топонима. Они су се временом одомаћили,

${ }^{1}$ Прелазак на ислам збио се по смрти Скендер-бега (Ђерђа Кастриотија), 1468, и турског освајања албанске територије (крај 15. века), да би од 17. и 18. века исламизација била интензивна (Arnold [1895] 1979; Jacques 1941: 128 и даље; Kaleshi 1975). По Елзију, „нова вера, ислам, као клин заривена између католичког севера и ортодоксног југа земље, постаће временом доминирајућа вера у земљи: до 1577. север и центар Албаније остају католички, југ православан, док се током првих деценија 17. века ситуација мења: између 30-50\% становништва северне Албаније прелази у ислам“ (Elsie 2006: 38).

\footnotetext{
${ }^{2}$ https://www.britannica.com/topic/biblical-translation
} 
поставши обликом свакодневног изражавања и описивања одређених појава и ситуација. Код појединих њихова религиозност или је изгубљена - семантика порука̂ надахнута божанском снагом сведена је на семантику прозаичности, на један нерелигијски, прецизније речено, на недуховни, општи ниво - или је очувана. Такав је, на пример, руски библизам с лексемом ,дух“ - (не) быльь в духе (=“/не/ бити расположен'), или српски израз имати духа - где лексема „не имплицира на бестелесно биће или Бога“, већ пре указује да је „реч о различитим садржајима реализованим у многобројним примарним и секундарним значењима речи $\partial x^{\prime \prime}$ (Ристић 1998: 170). Међутим, то не значи да су библијски фразеологизми потпуно изгубили на свом значају и вредности, да немају свој полазни смиcaо: њихова употреба је врло жива, сликовита и мотивисана ситуацијом сагледаном из властитог угла где се проналази оправдање и/или потврда да су библијске речи сасвим тачне. Отуда често чујемо да су чудни путеви Господюи, тражимо око за око, зуб за зуб, а неретко се позивамо и на Соломоново да ко другоме јаму копа са̂м у њу упада. Библизми су присутни око нас и живе у нама, само је питање колико смо некада свесни њиховог присуства и колико их можемо препознати као такве. Како је назначила Вуловић, по свом су карактеру и интернационални и национално-језички, са једне стране, а са друге, у језицима се разликују што због превода, што због начина „преузимања хришћанских представа и њиховог стапања с претхришћанским наслеђем, што се и огледа различито у језицима разних народа, а такође су важне за формирање овог фонда и специфичне језичке ситуације у разним историјским периодима. У вези с тим факторима појављују се и посебне језичке унутрашње тенденције и закони лексичко-семантичког развитка, што је све заједно довело до разликовања по облику, семантици и употреби библизама у разним језицима“" (Вуловић 2015: 35-36).

Библијски текст, попут религије, представља ,један облик знања, знање о значењу света и о сопственом животу“, а посебно и из разлога што „садржи представе о људима, о космосу, о коначности и вечности, смрти и животу, кривици или искупљењу, постанку и крају итд., коначно о свему што се људи тиче“ (Кußе 2012: 153, 151). Заправо, религијски дискурс се састоји од скупа комуникативних чинова или догађаја на које се односе, од преношења, очувања и развоја религијских представа на које се усмеравају (Лебедев и др. 2016: 20).

У односу на укупан број библијских фразеологизама, они формирани и с антропонимима и са топонимима чине релативно малу и затворену класу, пошто им је број који учествује у њиховом грађењу ограничен. То значи да библијских антропонима и топонима има много више, а само су одабрани традиционално усвојени и постали везани за фразеолошко-паремиолошки начин изражавања. Зато су ови библизми махом хомотипичне конструкције интернационално препознатљиве, а лексички, семантички и конотативно веома стабилни, петрифицирани изрази. За њихово правилно усвајање и употребу потребно је одређено предзнање ради разумевања њихове поруке у дискурсу.

Ако погледамо структуру и семантику библизама са ономастичком компонентом у албанском и српском, запажамо две велике групе, подударну и неподударну.

Прва група се састоји од две подгрупе, што ће рећи да је сачињавају сви апсолутно подударни, уз извесна могућа проширења или појаву синонимног облика, попут: 
Sodoma dhe Gomorra = Содома и Гомора

(si) kulla e Babilonit = (као) кула Вавилонска

si Davidi me Goliatin = као Давид са Голијатом

si (shën) Thomai dyshues/mosbesueshëm/jobesimtar $=($ као) неверни Тома

Samaritan i mirë (= „добри“) = милосрдни Самарићанин

bëhem/jam si farise = бити/nостати Фарисеј

i laj duart si Pilati = прати руке као Пилат

e çoj/shpie/dërgoj (dikë) nga Ponci te Pilati/nga Harodi te Pilati (='од Ирода до Пилата')

слати/водити (кога) од Понтија до Пилата

(jam) i kryqëzuar si Krishti $=($ бити $)$ разапет као Xрист

Посебан проблем у класификацији представља наредни фразеологизам:

(jam si) Magdalena e penduar (=“/бити као/ покајана Магдалена') бити Магдалена покајница/изигравати покајника/бити покајник

за кога Кончаревић (2018б: 28) каже да „очито, нема директне везе са Светим Писмом, него са химнографијом Цркве (стихира на јутрењу Велике среде, у којој се описује покајничка драма и нада на спасење жене грешнице, њена исповест и молитва)“, док га Јоана Папазафири сврстава у групу библијских новозаветних, понајпре због употребљеног антропонима (Палацарєі́рๆ 1995: 120-121).

У албанском и српском сусрећемо у књижевним делима, у говору и масмедијима наредни подударни израз (jam) si Adami dhe Eva = (бити) као $A д а м$ и Ева, чија семантика, уз кореспондирање с фразеологизмом (бити) у Адамовом/Евином костиму = (jam) me kostumin e Edamit/Evës, садржи и додатна значења - 'бити протеран, изгнан' (као Адам и Ева из раја); 'бити невин, чист' (као Адам и Ева у рају).

Друга подгрупа је структурно нешто разноврснија и да је боље објаснимо, ослањамо се на компаративно истраживање библијских фразеологизама руског лингвисте Гака (1997). По њему, два су главна фактора који утичу на то да се фразеологизми нужно разликују од језика до језика.

Први фактор је субјективне природе у виду реалија специфичних за једну земљу (или друштво) и за језик који се у њој говори. То се најбоље види у донекле измењеној структури изражавања где је једна реч замењена или с једном (неком другом) или са више њих.

Конкретно, у примерима на албанском и српском идентичан семантички смисао структурно је испољен на следећи начин:

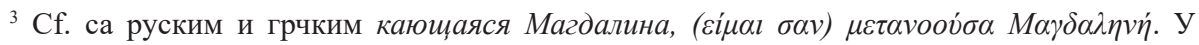
грчком се веома често сусреће и у колоквијалној употреби. 
а) у албанском и/или у српском употребљен је различит придев и/или именица као атрибут уз библијски антропоним:

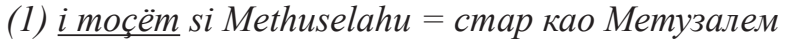 \\ (2) (као) убоги Лазар = (si) Llazari $i$ varfër}

(3) gjykimi i Solomonit / zgjidhja e Solomonit = соломонско решење

(4) Aдамова јабучииа = molla e Adamit

(5) ylli i Bethlehemit = звезда водиьа/витлејемска звезда

(6) $\underline{\text { ankthi }}$ i Abrahamit $=$ Аврамово искушене

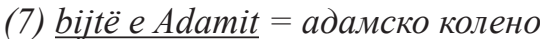

Подвучени именички делови синтагми су незнатно различити - албански придев $i$ тос̧ёm има, уз значење 'стар', и значење 'древан', а у наредној синтагми придев $i$ varfër буквално значи 'сиромашан’. Због семантичког варирања у српском, често се чује у колоквијалном дискурсу да је неко матор као Метузалем/Библија, што није одлика албанског. Српски фразеологизам (4) садржи деминутив који, иако постоји у албанском (mollëz) и може се појавити у овом изразу, обично се избегава: како ова именица примарно означава и јагодицу (јагодичну кост и јагодицу на прстима) и главу мача, да би се избегла семантичка забуна, уместо ње се чешће употребљава посебна лексема $f i k t h$, која означава само тај анатомски део. Да и у њеној употреби преовладава метафоризација и посебна концептуализација види се по томе што је основно њено значење 'недозрела смоква' преобликовано у складу са потребом одговарајућег семантичког описа.

У примеру (3) албанска именица gjykim односи се на суд, просуђивање, а варијанта са лексемом zgjidhja на избор, па се устаљени српски преводни еквивалент показује као нешто различит; међутим, уз варијанте соломоноски суд/ соломонска одлука, могуће га је сагледати као семантички сасвим подударан. Слично се може рећи и за (5): у српском је устаљенији и јаснији појам исказан именичким атрибутивом водиља (у Речнику Матице српске бележи се и варијанта водилица /PMC 1:404/), док би се номинални облик витлејемска звезда пре схватио дословно, у изворном библијском погледу, дакле, као звезда која се појавила и снажно засијала на небу у време Исусовог рођења. За српски је у овој номиналној конструкцији карактеристична инверзија лексичких чланова видљива и у другим номиналним изразима, попут камен темељаи, сузе радоснице, рак рана и слично, чиме се постиже посебан стилски ефекат и семантичко наглашавање које појачава поетску снагу пружајући лепоту и пуноћу изразу.

Пример (6) је данас устаљен афоризам пореклом из дела Серена Кјеркегора Страх и дрхтање (Пешић 2015: 32) с јасном алузијом на библијску причу о Авраму и његовој борби да ли да жртвује Богу свог сина или не. Разлику између албанског и српског оличава подвучена лексема која у албанском означава унутрашњу (психичку, емотивну) тескобу, немир, односно узнемиреност. У ширем погледу, указана конструкција одговара српском библизму жртвени јараи, док је њена синонимна албанска варијанта знатно измењена и сасвим 
прилагођена друкчијем начину лексичко-семантичког приказивања исте појаве према исламском погледу - dashi i kurbanit (=“курбански ован’). Пример такође показује како се исти семантички појам, унутрашње психичко превирање, дочарава различитим избором кључне лексеме која на то реферира. У односу на српски, где лексема искушење, према датим тумачењима (РМС 2: 490), поседује неколико значења - 'проверавање', ‘испробавање', ‘привлачност' и 'искуство' - лексема ankth ce показује као знатно бољи и прикладнији избор - садржи све потребне изражајне нијансе које потпуно покривају смисао човекове емотивне опхрваности и физичке немоћи.

У примеру (7), у варијанти на српском, употребљена је конструкција придев + именица, чије је значење 'осмо дете исте мајке, које је, по народном веровању, по свему изузетно, али без среће у животу’ (Оташевић 2012: 15). ${ }^{4}$ Милан Будимир, истакавши у студији Адамско колено да „се епитет адамски, или Адамов, у синтагми адамско колено могао распоредити на оба пола, иако је сасвим јасно да адамска јабука важи само за мушкарце, а адамско колено првенствено за женски род“ (Будимир 1967: 203), указује на три одлике указане конструкције:

- прва, „под лемом адамско колено читамо у Вукову Рјечнику: '(Adams Stamm), nennt mand das Muster einer Ehefrau, plus quam Penelope', тј. 'жена боља од Пенелопе'“ (op. cit, 202) као „хришћанску варијанту опште и врло старе представе о примитивном човеку, његовој доброти и мирољубовости“ (207), што показује да се односи само на женски пол и да садржи искључиво позитивну одлику потврђену и у лексичком материјалу РСАНУ (Вуловић 2015: 176);

- друга, „у лексичком материјалу Иститута за српскохрватски језик (...) јавља се и друкчија, па чак и супротна семантичка нијанса ове синтагме (...) која гласи: ‘адамско кољено', рече се за непоштену (sic!) жену, за то се често дода проклето (адамско кољено)““(Будимир 1967: 202);

- трећа, „да је у индоевропском патријархату отац стављао сина на колено и на тај начин га признавао као своје законито дете“ (op. cit, 210).

У албанској варијанти, међутим, с именицом у множини, bijtë, семантички се истиче порекло човека, па зато „синови Адама“ нису ништа друго до његови директни, „исконски потомци“. У оба језика наилазимо и на хомотипичан фразеолошки израз са потпуним семантичким поклапањем - Aдамово племе = fisi $i$ Adamit.

б) у албанским номиналним конструкцијама антропоними у својству одредбених речи стоје у генитиву, у одговарајућим српским налази се присвојни придев:

$$
\begin{gathered}
\text { gostia/festa e Baltazarit }=\text { Валтасарова гозба } \\
\text { arka/varka /anija e Noes/Nuhut }=\text { Нојева барка } \\
\text { puthja e Judës }=\text { Јудин пољубац }
\end{gathered}
$$

\footnotetext{
${ }^{4}$ Будимир у поменутом раду додатно расправља о значењу броја осам, а више података о изражавању порекла преко колена даје Бјелетић (1999: 56 и даље). 
me kostumin e Adamit/Evës $=$ у Адамовом/Евином костиму

$$
\begin{gathered}
\text { flijimi } \underline{\text { i Abrahamit }}=\text { Аврамова жртва } \\
\text { mëkati } \underline{\text { i Adamit }}=\text { Адамов грех } \\
\text { brinja } \underline{\text { e Adamit }}=\text { Адамово ребро }
\end{gathered}
$$

Примери показују незнатна структурна неслагања између албанског и српског, која задиру у домен граматичког (морфосинтаксичког) устројства и једног и другог језика: оба облика су употребљена у својој главној синтаксичкој функцији да семантички укажу на припадност вршећи функцију атрибутивне одредбе. За сваки језик је ово устаљен облик изражавања и отуда представља специфичност непрепознатљиву у оном другом. Антропоним Nuhu je, заправо, Ноје, а ушао је у албански преко турско-арапског утицаја.

Одступање на лексичко-структурном нивоу износи и наредни номинални фразеологизам који у албанском гласи gomari $i$ Valaamit, док у српском има две варијанте - Валамова магарииа/Валамов магараи. Ако упоредимо ове

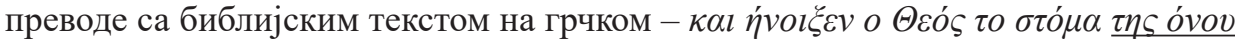
- увидећемо да је прва српска варијанта ближа изворнику. И у Даничићевом и у албанском преводу стоји управо лексема магарица/gomarica што показује очуваност изворности оригинала. Ова неосетна разлика објашњава се тиме да је говорни језик однео превагу над библијским текстом - то је логички синоним (Murphy 2003: 146) који омогућава да се сачува семантичка суштина поруке: варијације између лексема „магарац“ и „магарица“ су дозвољене због праве (и/ или апсолутне) лексичке синонимије унутар одређеног контекста (Cruse 2000: 157; Lyons 1981: 148), а избор једне или друге лексеме не утиче на промену семантике.

Исту ситуацију видимо и у наредном примеру - shenja/damka/vula e Kainit $(=$ 'знак/жиг' $)=$ Каинова стигма/Каинов печат/ожиљак - где варирање синонимних лексема различитог порекла унутар истог контекста не мења значење, али зато избор лексеме доприноси њеном ефекту, и то тако што се интензивира и појачава изражајност поруке.

Албански фразеологизам shkoj пё Kalvar/kryq (='отићи на Калварију/крст’) донекле је сличан српском проћи Голготу/отићи на Голготу: у оба случаја реч је о великим мукама које човек трпи, те се оне концептуално и метафорички изједначавају с Христовим проживљеним на крсту. Иако су речи Калварија и Голгота синонимне, видљива је разлика њихове употребе, што се може објаснити грчким утицајем на српски (ГодүоӨ́́s), а латинским на албански (Calvaria), ${ }^{5}$ чиме је у обе фразеолошке јединице непосредно инкорпорирана језичка, културна и конфесионална одлика средина из којих су преузете. ${ }^{6}$

\footnotetext{
${ }^{5}$ Обе речи су грчког порекла.

${ }^{6}$ Када је реч о утицајима ове врсте, разлике су видљиве и код антропонима Baraba/Bapaвa, Abraham/Аврам, Baltazar/Bалтазар, Jakob/Јаков као и код топонима Babilon/Baвилон, Bethlehem/Витлејем, где је реч о витацизму. По Стевановићу (1964: 207), „само ове разлике, у по једном гласу, чак ни у терминологији, ниуколико не отежавају разумевање тих речи ни на једној ни на другој страни, у било коме од два облика се оне употребиле“.
} 
Други фактор, према мишљењу В. Гака, јесте објективан: како залази у домен културе и традиције сваког друштва, промена у фразеолошким библизмима види се у различитим степенима значења и употребе библијских фразеолошких конструкција.

Лексичке разлике као посебне варијације унутар истог структурног поља видљиве су у синонимним библијским изразима на албанском:

\section{që nga mosha/kohët/kohërat/qepallat e Adamit që në kohën e Noes/Nuhut}

који имају и своје синонимне облике - qё nga kohët e sulltan Pekmezit/e baba Qemos (=“од времена султана Пекмеза/чича Ћеме'). Ови облици семантички означавају оно што се у српском исказује фразеолошким номиналним конструкцијама са такође синонимним лексичким варијацијама: од Адама и Еве/од Адамовог колена/од давнина/Кулина бана/од пре (Нојевог) потопа. Облици (kohët e) sulltan Pekmezit/e baba Qemos могу се изједначити с обликом од Кулина бана - то су само за албански и српски свет посебне културноспецифичне ознаке у виду личности, историјски потврђених или не, задржане у народном сећању као репери одмеравања (про)тока времена и то од неког тренутка који је везан за ту личност, узету као полазна тачка. Наведени номинални фразеологизми се могу сагледати као културно-историјски облици општих народних библијских календара у облику оријентира за рачунање (про) тока целокупног времена. Албански облик qepallat e Adamit специфична је номинална конструкција: ${ }^{7}$ управна лексема, изгубивши буквално значење 'капци', потпуно је метафорички преиначена у ознаку 'памтивек', па је њен најприближнији српски неподударни преводни еквивалент *од када је света и века. Из тог разлога ове конструкције нису нелогичне, а сасвим су у складу с народним појмом сагледавања (про)тока времена. Избор између синонимних варијаната у оба језика указује да је реч о одабиру одговарајуће полазне тачке на линеарној временској оси са задатком да се прикаже однос говорног лица према прошлом времену, односно прошлости уопштено. Тако се, на пример, конструкције пре Адама, (почев) од Адама и Еве/од Адамовог колена, од пре Христа не доживљавају семантички исто као конструкција од пре (Нојевог) nomona: како су Адам и Ева Нојеви претходници, знатно су старији од њега, а Христ много млађи. Конструкције с Адамом су додатно важне: после његовог протеривања из раја, „почиње историја људске врсте на земљи и на тај начин је хронолошки маркирана“ (Мршевић-Радовић 2014: 85). У српском постоји и фразеологизам с лексичком инверзијом од Адама почети/развести (синониман са почети од Кулина бана) који одговара албанском nis qё nga kohërat e Noes/

\footnotetext{
${ }^{7}$ Колико смо успели да истражимо, овакав фразеолошки склоп, осим у албанском, постоји још само у аромунском (цинцарском) језику, додуше у нешто измењеном облику, без библијског антропонима - di pi peanili di oclji (=“још од капака очију'). Мотивација за њихов настанак би се могла везати за око (вид) те сећање (памћење) и претходно стечено знање: када се подигну капци, јасније се види, добија се бољи преглед и стиче се бољи увид у садашњост преко сагледавања прошлости.
} 
baba Qemos. Мада ова нијансирања не морају постојати у свести говорног лица, његово коначно опредељење за неку од варијаната покушај је његовог темпоралног синоптичког прецизирања без залажења у указане разлике.

Неподударност између две фразеолошке слике види се у следећим албанским идиотипичним конструкцијама (номиналним и глаголским) с библијским антропонимима који се преносе на српски или друкчијим облицима фразеологизације или сасвим нефразеолошки, и то „због разлике у књижевној традицији, или чак и у природи језика“" (Сибиновић 2009: 129):

bëhem endacak/bredh rrugëve si Kaini (=`бити бескућник/обијати друмове као Каин') *потуцати се

(jam) Adami i vjetër (=“/бити/ стари Адам’) *не покајати се/*не одрећи се старог/*бити грешник

këtë thonë Moisiu dhe profetët (='тако кажу Мојсије и пророци’)

*тако је то/*тако мора бити/*нема друге до

të këndosh Lazarin (='да опеваш Лазара') ${ }^{8}$

*што кукаш над собом/својом судбином

Слично запажамо и у српском фразеологизму бити стрпљив/имати стрпљьеља као Јов која се на албански преноси друкчијом метафоризацијом kam durim prej guri/hekuri - како буквално значи 'имати стрпљење од камена/ челика', сасвим је јасна мотивација њеног настанка.

У српском се често каже за некога даје (права) бараба-библијски антропоним Варава ${ }^{9}$ сведен је на ниво апелатива (Peti 1999: 108; Opašić 2014: 502) поставши тиме део општег лексичког фонда, и метафорички стекавши значење 'подлац', 'нитков', с јасном семантичком референцом на библијски текст где се Варава описује као разбојник. У албанском овакве алузије нема, па се као преводни еквивалент јавља нулти структурно-семантички израз (jam) xhagajdur.

У обрнутом смеру, приликом анализе грађе на албанском језику, наишли смо на следећи пример: Ku ishe ti, Adam? (='Где си био ти, Адаме?') који су албански лингвисти означили као позајмљеницу, калк и фразеологизам (Jashari 2007, Zaçellari 2015, Gjergji 2016: 258) фреквентне употребе. Појава му се везује не толико за Библију колико пре за снажне утицаје из енглеског језика, са телевизије, масмедија и глобалне комуникације који су га учинили општепознатим и прихваћеним са значењем 'закаснити на неки важни догађај, не појавити

\footnotetext{
${ }^{8} \mathrm{Cf}$. са руским петь Лазаря. Поређења ради, у грчком оваква конструкција уопште не постоји.

9 Док је антропоним доживео новију, витацистичку, промену у изговору, у фразеолошкој јединици сачуван је стари, бетацистички начин изговора.
} 
се када треба, рећи свој суд о нечему врло важном онда када је већ прошло време или је сувише касно'. Српска језичка грађа не бележи овај израз - изузетак представља наслов књижевног дела немачког писца Хајнриха Бела Где си био, Aдаме? - а уз позивање на библијски текст (Постање 3: 96), дословни превод указане конструкције био би сасвим прихваљив и разумљив. Међутим, најбољи преводни еквивалент на српском припадао би нултом структурно-семантичком нивоу: *касно Марко на Косово стиже.

\section{3. УМЕСТО ЗАКЉУЧКА}

За албански и српски фразеолошки корпус са ономастичким компонентама као кључним речима може се рећи да је то једна релативно мала и затворена поткласа у оба језика (најбројније су јединице с антропонима /28:26/ у односу на оне са тономимима /по 4/ и етононимима /по 2/), док је сама класа структурно и семантички двојака: поред апсолутно подударних, уз категорију делимичне структурне подударности, постоји и један мањи број оних с нултим степеном структурно-семантичке еквиваленције. Уз извесна лексичка одступања, посебно када је реч о синонимним, дублетским облицима, понекад и о више различитих облика, комутација могућих лексема не ремети битније основно значење библијског фразеологизма, а свакако доприноси интензивирању набоја исказа и његовом нијансирању како би се путем жељеног облика постигао потребан семантичко-изражајни ефекат. Осим што „преводи Библије представљају први корак у процесу инкултуризације светописамске поруке у новој култури“ (Кубат, Драгићевић 2018: 337), поједини елементи из библијског текста с ономастичком компонентом су временом инкорпорирани у семантичко-лексичку фразеолошку слику и албанског и српског језика, а извршене адаптације, сходно потребама њихових говорника, односно метафоричкој и симболичкој концептуализацији, постале су појмовне метафоре, чија је „,bit razumijevanje i doživljavanje jedne vrste stvari pomoću druge“" (Lakoff, Johnson 2015: 5).

Библијски фразеологизми с указаним ономастичким компонентама чине групу општекултурних и културно-књижевних фразеологизама ученог карактера, те представљају надоградњу у односу на такозване основне, националне. Услед релативно раширене употребе, стекли су ван оригиналног библијског контекста конотативну функцију опште именице, те је зато могуће говорити о омниперсоналној употреби имена (Marković 2010: 191) јер „бесмислена и безначајна имена у њиховој генези не постоје“ (Булгаков 1999: 224). Иако „svako ime (...) može postati osnova za tvorbu apelativa, odnosno poprimiti širi semantički kontekst i apelativizirati se“ (Barac-Grum 1990: 17), што је посебна одлика националних фразеологизама, интернационални фразеологизми, међу које се сврставају и библизми, садрже устаљене антропониме, етнониме и топониме у чврстим структурно-семантичким оквирима испољеним као петрифицирани (стереотипични). За њихову употребу потребно је познавање библијског контекста и/или везе са библијским текстом, јер саิма ономастичка компонента, без позадинске слике као пратећег објашњења, не значи ништа: зато је њихова употреба строго контекстуално одређена и концептуално јасно постављена, при чему антропоним, етноним, односно топоним, чини окосницу и метафоричког и асоцијативног поља. 
Без обзира на све разлике, библијски фразеологизми са ономастичком компонентом у савременом албанском језику су великим делом подударни са српским и обратно, што неминовно указује да су оба народа сачувала заједничке елементе, који их много више приближавају него удаљавају како на духовном тако и на културном пољу.

\section{Цитирана литература}

Бјелетић, Марта. „Кост кости (делови тела као ознаке сродства)“. Делови тела. Кодови словенских култура 4, 1999: 48-67.

[Bjeletić, Marta. „Kost kosti (delovi tela kao oznake srodstva)”. Delovi tela. Kodovi slovenskih kultura 4, 1999: 48-67]

Будимир, Милан. Са балканских источника. Београд: СКЗ, 1969.

[Budimir, Milan. Sa balkanskih istočnika. Beograd: SKZ, 1969]

Булгаков, Сергей Николаевич. Философия имени. Москва-Санкт Петербург: Искусство-Инопресс, 1999.

[Bulgakov, Sergeî Nikolaevich. Filosofiiā imeni. Moskva-Sankt Peterburg: IskusstvoInopress, 1999]

Вуловић, Наташа. Српска фразеологија и религија. Лингвокултуролошка истраживања. Београд: Институт за српски језик САНУ, 2015.

[Vulović, Nataša. Srpska frazeologija i religija. Lingvokulturološka istraživanja. Beograd: Institut za srpski jezik SANU, 2015]

Гак, Владимир Г. «Особенности библейских фразеологизмов в русском языке (в сопоставлении с французскими библейскими фразеологизмами)». Вопросы языкознания 5, 1997: 55-65.

[Gak, Vladimir G. "Osobennosti bibleǐskikh frazeologizmov v russkom iazyke (v sopostavlenii s frantsuzskimi biblě̌skimi frazeologizmami)““. Voprosy iazykoznaniia 5, 1997: 55-65]

Јовановић, Зоран Р. „Библија-апсолутни бестселер светске књижевности“. Преводилац 3-4, 2003: 31-55.

[Jovanović, Zoran R. „Biblija-apsolutni bestseler svetske književnosti“. Prevodilac 3-4, 2003: 31-55]

Кончаревић, Ксенија. Језик и култура - славистичка перспектива. Београд: ИК Јасен, 2018а.

[Končarević, Ksenija. Jezik i kultura - slavistička perspektiva. Beograd: IK Jasen, 2018a]

Кончаревић, Ксенија „Фразеологизми инспирисани светим Предањем у руском и српском језику“. Славистика XXII/2, 2018б: 25-35.

[Končarević, Ksenija „Frazeologizmi inspirisani svetim Predanjem u ruskom i srpskom jeziku“. Slavistika XXII/2, 2018b: 25-35]

Кубат, Родољуб, Предраг Драгићевић (ур.). Лексикон библијске егзегезе. Београд: Службени гласник - Православни богословски факултет, 2018.

[Kubat, Rodoljub, Predrag Dragićević (ur.). Leksikon biblijske egzegeze. Beograd: Službeni glasnik - Pravoslavni bogoslovski fakultet, 2018]

Лебедев, Владимир Ю., Александр М. Прилуцкий, Вячеслав Ю. Викторов. Религиоведение: учебник для академического бакалавриата. Москва: Издательство Юрайт, 2016. 
[Lebedev, Vladimir $\widehat{\text { Iu. }}$, Aleksandr M. Prilutskiı̌, Viacheslav $\widehat{\mathrm{Iu}}$. Viktorov. Religiovedenie: uchebnik dlia akademicheskogo bakalavriata. Moskva: Izdatel'stvo Iurăit, 2016]

Мршевић-Радовић, Драгана. Фразеологија и национална култура. Београд: Друштво за српски језик и књижевност Србије, 2014.

[Mršević-Radović, Dragana. Frazeologija i nacionalna kultura. Beograd: Društvo za srpski jezik i književnost Srbije, 2014]

Пешић, Александар. „Аврам и вера у Страху и дрхтању“. Годишњак Учитељског факултета у Врању VI, 2015: 27-40.

[Pešić, Aleksandar. „Avram i vera u Strahu i drhtanju“. Godišnjak Učiteljskog fakulteta u Vranju VI, 2015: 27-40]

Ристић, Стана. „Значење речи дух и душа у савременом српском језику (концептуална анализа)“. Наш језик XXXII/3-4, 1998: 168-178.

[Ristić, Stana. „Značenje reči duh i duša u savremenom srpskom jeziku (konceptualna analiza)“. Naš jezik XXXII/3-4, 1998: 168-178]

Сибиновић, Миодраг. Нови живот оригинала. Београд: Просвета-Алтера-УНСПС, 2009.

[Sibinović, Miodrag. Novi život originala. Beograd: Prosveta-Altera-UNSPS, 2009]

Стевановић, Михаило. „Неке лексичко-стилске разлике, а не језичке варијанте“. Наш језик XIV/3-4, 1964: 197-226.

[Stevanović, Mihailo. „Neke leksičko-stilske razlike, a ne jezičke varijante“. Naš jezik XIV/3-4, 1964: 197-226]

Arnold, Thomas Walker. The Preaching of Islam. A History of the Propagation of the Muslim Faith. London; Luzac, [1896] 1979.

Barac-Grum, Vida. „Mogućnost preobrazbe vlastitog imena“. Rasprave Zavoda za jezik 16/1,1990: 15-20.

Gjergji, Shpresa. Rreth relativizmit gjuhësor në përqasjen frazeologji e anglishtes/ frazeologji e shqipes. Tiranë: 2016. (<http://www.doktoratura.unitir.edu.al/wp-content/uploads/2017/02/DOKTORATA-Shpresa-Gjergji.pdf $>12.02 .2021$ ).

Elsie, Robert. Letërsia shqipe. Një histori e shkurtër. Tiranë: Skanderbeg books, 2006.

Jacques, Edwin Everett. The Islamisation in Albania under the Turks. Boston: 1941 (< https://open.bu.edu/handle/2144/4209>)

Cruse, Alan D. Meaning in Language: An Introduction to Semantics and Paradigmatics. Oxford: Caledon Press, 2000.

Kaleshi, Hasan. 'Das türkische Vordringen auf dem Balkan und die Islamisierung. Faktoren für die Erhaltung der ethnischen und nationalen Exstenz des albanishen Volkes“. [In:] Peter Bartl, Horst Glassl (Hrgs.) Südeuropa unter dem Halbmond. Untersuchungen über Geschichte und Kultur der südosteuropäischen Völker während der Türkenzeit. Prof. Georg Stadtmüller zum 65. Geburtstag gewidment. Munich: Trofenik, 1975: 125-138.

Kuße, Holger. Kulturwissenschaftliche Linguistik. Eine Einführung. Göttingen: Vandenbroek \& Ruprecht Gmbh., 2012.

Lakoff, George, Johnson, Mark. Metafore koje život znače. Zagreb: Disput, 2015.

Lyons, John. Language and Linguistics: An Introduction. Cambridge: Cambridge University Press, 1981.

Marković, Ivan. „O uporabi i značenju imenâ u hrvatskom jeziku“. Folia onomastica 19, 2010: 175-202.

Murphy, Lynne M. Semantic Relations and the Lexicon-Antonymy, Synonymy, and 
Other Paradigms. Cambridge: Cambridge University Press, 2004.

Opašić, Maja. „Općeeuropski frazemi hrvatskog jezika u Rječniku stranih riječi Bratoljuba

Klaića“. Rasprave Instituta za hrvatski jezik i jezikoslovlje 40/2, 2014: 411-434.

Peti, Mirko. „O tzv. sadržaju imena“. Folia onomastica croatica 8, 1999: 97-112. Zaçellari, Manjola. "Features of Phraseological Units of Latin and Neolatin Origin". International Journal of Arts and Sciences 8/1, 2015: 1-8.

\section{Извори}

Библија или Свето писмо Старога и Новога Завјета (превели Ђуро Даничић и Вук Стефановић Караџић). Београд: Библијско друштво, 1996.

[Biblija ili Sveto pismo Staroga i Novoga Zavjeta (preveli Đuro Daničić i Vuk Stefanović Karadžić). Beograd: Biblijsko društvo, 1996]

Оташевић, Ђорђе. Фразеолошки речник српског језика. Нови Сад: Прометеј, 2012.

[Otašević, Đorđe. Frazeološki rečnik srpskog jezika. Novi Sad: Prometej, 2012]

Речник српскохрватског књижевног језика (1-6). Нови Сад: Матица српска, 1995.

[Rečnik srpskohrvatskog književnog jezika (1-6). Novi Sad: Matica srpska, 1995.]

Речник српскохрватског књижевног и народног језика САНУ. Београд: Институт за српски језик САНУ, 1959-.

[Rečnik srpskohrvatskog književnog i narodnog jezika SANU. Beograd: Institut za srpski jezik SANU, 1959-]

Bibla-Dhjata e Vjetër dhe Dhjata e re (përkthimi Diodati i Ri 1991-1994). Tiranë: Shoqata shqipëtare e Biblës, 1995.

Gjevori, Mehmet. Frazeologjizma të gjuhës shqipe. Prishtinë: Rilindja, 1988.

Jashari, Ali. Fjalor me shprehje të huazuara në gjuhën shqipe. Tiranë: Botimet Dudaj, 2007.

Matešić, Josip. Frazeološki rječnik hrvatskoga ili srpskoga jezika. Zagreb: Školska knjiga, 1982.

Thomai, Jani. Fjalor frazeologjik i gjuhës shqipe. Tiranë: EDFA.

Fjalor i Gjuhës Shqipe, Akademia e Shkencave e Shqipërisë, Tiranë, 2006.

Fjalor Frazeologjik i Gjuhës Shqipe, Akademia e Shkencave e Shqipërisë, Tiranë, 1999.

Fjalor i gjuhës së sotme letrare shqipe I-II. Prishtinë: Rilindja.

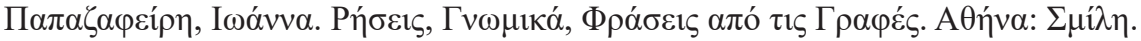

[Papazafeírh, Iwónna. Ríseic, Gnwmikó, Fróseiç apó tiç Graféc. Athína: Smílh]

\section{Online речниции}

http://www.shkenca.org/content/view/142/27/

https://fjalorthi.com/

https://fjale.al/

\section{Cajmozрафија}

https://www.britannica.com/topic/biblical-translation $(<19.06 .2021)$ 


\title{
О БИБЛЕЙСКИХ ФРАЗЕОЛОГИЗМАХ С ОНОМАСТИЧЕСКИМ КОМПОНЕНТОМ В СОВРЕМЕННОМ АЛБАНСКОМ И СЕРБСКОМ ЯЗЫКАХ
}

\begin{abstract}
Резюме
В статье проводится сравнительный анализ библейских фразеологизмов, ключевым словом которых являются ономастические компоненты (антропонимы, топонимы) в современных албанском и сербском языках. Материалом для исследования послужили толковые и двуязычные словари общего типа, а также фразеологические словари. Каждый из языков является как входным, так и выходным. Классификация выполнена на основании степени их соответствий, исходя из которых выделены три группы: две относительно соотносимые (с абсолютной и частичной эквивалентностью) и третья, самая меньшая, в которой объединены фразеологизмы с нулевым уровнем фразеологической и семантико-структурной эквивалентности.
\end{abstract}

Использование библейских антропонимов во фразеологизмах строго определено контекстом и концептуально четко установлено, при этом антропонимы формируют основу как метафорического, так и ассоциативного семантического поля, в результате чего они и являются структурно и семантически окаменевшими формами выражения.

Несмотря на все различия, библейские фразеологизмы с антропонимами в албанском языке в значительной степени совпадают с сербскими, и наоборот. Данный факт указывает на то, что оба народа сохранили общие элементы, которые их сближают гораздо больше, чем разделяют, в духовной и культурной сфере.

Ключевые слова: библейские фразеологизмы, ономастические компоненты, антропонимы, этнонимы, топонимы, албанский, сербский, соответствие. 